\title{
Beyond the rhetoric of sprawl: storylines and the discursive construction of the sustainable city
}

\author{
J. Rogers \\ RMIT University, Australia
}

\begin{abstract}
This paper is concerned with the way in which the ideal of the 'sustainable city' is currently spoken and written about in Australia. Using the 2003-2005 Australian Federal Government's House of Representatives Standing Committee on Environment and Heritage's Inquiry into Sustainable Cities as a case study the paper employs a discursive approach to analyse the Inquiry documents. The paper argues that use of the word sprawl has powerful metaphorical importance in sustainable city discourse, suggesting alternative stories about the future of cities. The first, the story of decline, suggests out of control growth of cities that threatens not only the resource base, but also 'nature', agricultural land and social stability. It also leads to isolation, loneliness, boredom, crime, obesity and a whole litany of other evils. The alternative storyline, the story of control, is presented as the only choice 'we' really have - the compact, contained city is a place where resources are used wisely, 'nature' and agricultural land are protected, and there is a sense of 'community'.

However, it is the contention of this paper that the dominant focus on sprawl in sustainable city discourse effectively closes down rather than opens up discussion about the future because embedded in the use of the term sprawl is a predefined conclusion. In addition, the abundant use of pronouns in the discussion paper, the inquiry and in sustainability literature more broadly - 'we, 'our', 'us' - all denote a common responsibility and a common pathway that encourages compliance, not the active and open ended involvement of citizens in shaping their future.
\end{abstract}

Keywords: sustainability, suburbs, sprawl, equity, storylines, policy, cultural stereotypes, democracy, community. 


\section{Introduction}

It has become commonplace to begin any discussion of sustainability with the observation that it is a contested concept with multiple meanings. As Becker et al. [1] have observed 'the only consensus on sustainability appears that there is no shared understanding'. However, in sustainable city discourse, as Whitehead [2] has noted, despite debate over the extent and severity of the socio-ecological problems facing urban areas '...there does appear to be a considerable degree of consensus over how the international political community should address the complex hybrid of social, economic and ecological problems that face urban areas. Whitehead noted the dominance in contemporary research on the practical implementation of sustainable development as a policy goal, and the lack of analysis of the sustainable city as an object of political contestation and struggle (Whitehead [2]). Defining the 'problem' of 'unsustainable cities' in instrumental terms leads '...ineluctably to the preferred solution' (Harrison [3]); which is also an instrumental one that forecloses any discussion that may involve questions of distributional equity or political participation.

One of the most commonly shared understandings on which there is a great deal of consensus is that a 'sustainable city' is compact and contained not sprawling and therefore in Australia at least policy discussions are dominated by developing techniques and approaches to control sprawl. The distinction between compact and sprawling cities is often presented as contrasting future visions or storylines (Hajer [4]). These two storylines - one of decline and one of control (Stone [5]) - are based around a series of dualisms or binary oppositions, beginning with compact versus sprawl but also including sustainable/unsustainable, efficiency/waste, lively/boring, viability/decline, responsible/irresponsible. In this paper I argue that the use of the word sprawl effectively functions as a metaphor suggesting these alternative stories about the future of cities and '...by uttering a specific element one effectively reinvokes the storyline as a whole' (Hajer [4]).

The paper is based on a case study of the Australian Government's House of Representatives Standing Committee on Environment and Heritage's Inquiry into Sustainable Cities 2025. While the inquiry process itself did not result in the development of specific policies or strategies, the inquiry documents provide a rich understanding of the way in which the sustainable city is currently spoken and written about in Australia.

\section{The House of Representatives Standing Committee on Environment and Heritage: Inquiry into Sustainable Cities}

The Australian Federal Government's House of Representatives Standing Committee on Environment and Heritage's Inquiry into Sustainable Cities began in August 2003 with the final report tabled in Federal Parliament on 12th September 2005. During the process of the inquiry 196 submissions were received and 15 public hearings were held in 6 capital cities. The Inquiry called for discussion and input 'from a wide range of professions, community groups, 
local and state governments, researchers, businesses, industry associations and individuals' House of Representatives Standing Committee on Environment and Heritage [6] and so one would expect a wide range of divergent views about what constitutes a sustainable city. However, there is instead a great deal of commonality and agreement. And despite the appeal to a broad range of interests noticeably absent from the discussion were voices from the social welfare sector, from consumer groups or from representatives from indigenous and ethnic organisations. One of the reasons for this absence is that the boundaries around how discussions should proceed were firmly established from the outset.

\subsection{The framing of the inquiry: the discussion paper}

The discussion paper, released at the launch of the Inquiry in 2003, was organized around the familiar sustainable city storylines of sprawl or containment. It begins with an imperative - 'Cities of the Future must be sustainable cities' (House of Representatives Standing Committee on Environment and Heritage [6]) and, as with most definitions of 'sustainable cities', a link is made between the environment, social equity and economic growth with an emphasis on changing settlement patterns. So the cities we 'must' have 'will'

'...integrate the built and natural environment. The sustainable city will assist in retaining the biodiversity of Australia, have a developed infrastructure that gives efficient and equitable access to services and utilities, preserve the essentials of the 'Australian lifestyle' and contribute to the economic wealth of the nation', House of Representatives Standing Committee on Environment and Heritage [6]

The 'city' is here personified as being an active agent of change. It is the city itself that 'will assist in retaining biodiversity', 'have a developed infrastructure' and will 'preserve the essentials of the 'Australian lifestyle' while contributing to economic growth. Clearly future-focussed and in control the sustainable city is by implication here contrasted to the 'out of control' unsustainable city. Use of imperative language - 'will have', or 'must' have - demonstrate that there is little choice in terms of what a sustainable city 'will' do.

The terms of reference for the inquiry were quite specific about what a sustainable city would be like spatially. These were to investigate:

- The environmental and social impacts of sprawling urban development;

- The major determinants of urban settlement patterns and desirable patterns of development for the growth of Australian cities;

- A 'blueprint' for ecologically sustainable patterns of settlement, with particular reference to eco-efficiency and equity in provision of services and infrastructure;

- Measures to reduce the environmental, social and economic costs of continuing urban expansion; and

- Mechanisms for the Commonwealth to bring about urban development reform and promote ecologically sustainable patterns of settlement 
(House of Representatives Standing Committee on Environment and Heritage [6]).

And so 'the problem' that was to be addressed during the inquiry was clearly articulated from the outset and that problem is sprawl. It is not surprising therefore that a dominant focus throughout the inquiry was on strategies to reduce sprawl.

\section{The problem with 'sprawl'}

Use of the term sprawl immediately conjures up images of the uncontrolled, unplanned growth of cities that 'sprawl' and are difficult to contain. This lack of control and containment and the associated 'costs' were evoked in a number of ways throughout the Inquiry drawing on already existing and well rehearsed storylines. The following outlines the dominant ways in which the 'problems' of sprawl were spoken about during the Inquiry. It demonstrates the way in which the term sprawl functions as a 'short cue' (Hajer [7]) to frame a discussion amongst diverse interest. Used as a metaphor to reference a range of urban ills, it also suggests the panacea to them all. One of the major concerns in the discussion paper and in many of the submissions was the impact of urban sprawl on the 'environment'. Submission 177 from a local environmental group for instance complained, 'With the most rapid population growth in the country, we are watching in horror as our floodplains, fields, farms, forests and fisheries are covered in housing' (House of Representatives Standing Committee on Environment and Heritage [8]). Here 'housing' is understood not as shelter or even as homes which would conjure up quite different images but as a consumptive land use, a point reiterated in submission 45 from a private individual, and submission 87 from an NGO which claimed that sprawl not only consumes, but swallows land on the urban rural fringe:-

Environmentally, urban sprawl means many of our major cities have encroached and swallowed enormous tracts of surrounding arable agricultural land, shifting the rural lands that provide food sources further and further from our cities where the food is consumed (House of Representatives Standing Committee on Environment and Heritage [8]).

Along with 'swallowing', other metaphors used to denote the impact of 'sprawl' included eating (submission 12), 'spreading' (submission 28), 'encroaching' (submission 28), and 'feed upon' (submission 50). And while few participants would probably agree that cities do in fact function in this way the use of organic metaphors and personification reinforce the dominant storyline of decline and the need to bring the situation under control. For several of the submissions this was the single most important imperative in terms of future sustainable cities because as noted in submission 12, 'New urban areas must also not encroach on existing natural forest areas or other significant natural areas, as there is already enough cleared land...people should not be building in forest areas and then complaining about the fire risk' (House of Representatives Standing Committee on Environment and Heritage [8]). This is also true of 
agricultural land, according to one NGO (submission 44), who pointed out that 'Some of the most productive land in Australia is being paved' (House of Representatives Standing Committee on Environment and Heritage [8]).

But what is this 'natural environment' that exists outside of the city boundaries that is threatened by sprawl? In a revealing exchange during the public inquiry between the Chair and a representative of an NGO Environment Victoria the 'ecological' merits of land set aside in Victoria as green wedges was questioned as follows:-

CHAIR - Green wedge by definition, down our way, is clapped-out farming land, and it is green only because the cows have had a gnaw at it for about the last hundred years. It would seem, in sustainability terms, that a wiser definition would be 'sustainability wedge'. If the ecology is the greatest value and virtue in one part of the green wedge, leave it there. Down our way, the ecological value of those areas is really difficult to identify, yet we know that some garden based spaces-even industry, if there were an aggressive revegetation program as part of a technology park or something-would be a far more productive sustainability investment because people would not be spending all day in their cars. You would be diversifying the community activity, using that space to enhance sustainability and not just leaving it as a place for agistment and cow dung. I am just wondering if sometimes we get wrapped up in the rhetoric and-it sounds like a terrible description-lose sight of the forest for the trees when there are not any there. I wonder whether there is a maturation required in the ideas, rather than saying, 'There's a green wedge. It's great. It's got a couple of dairy cows on it but, other than that, we are not quite sure what it does.'

Mr BARRESI-Not out my way.

CHAIR - That is what I am saying and that is the point - out your way a proper assessment of those green wedges is the ecological value and the habitat virtue of it, whereas down our way, Phil, if I planted a couple of eucalypts out there, that would be the biggest environmental enhancement seen for ages.

Ms Brown-It depends on how you manage those areas, obviously. The key is working with local councils and state governments to manage the green wedges to actually assist the biodiversity growth and to manage it whether for agricultural or other sorts of uses-tourism and that sort of thing. We need to be very careful of what happens with the green wedges. We cannot just draw a line and leave it. The other thing you highlight is that, apart from the green wedges, there is still plenty of opportunity to enhance biodiversity and do other sorts of projects that are inside the city boundaries that are not necessarily green wedge. I think you are right: it does not have to be left as a boundary so simplified in that way (House of Representatives Standing Committee on Environment and Heritage [9]). 
What this brief exchange reveals is the way in which the dominant storyline generalises the problem of the 'unsustainability' of cities but also the role that language plays. Containment policies and green wedges are seen as necessarily a good thing because they contain and control urban sprawl and in a simple reversal of the binary preserve 'nature'. What the extract suggests is that the leap from generalised descriptions of the impact of sprawl to prescription stopping sprawl, or what Rein and Schon [10] refer to as the 'normative leap', is based more on rhetoric and less on what actually exists on the ground. In this case it would seem adherence to commonly shared understandings matters more than what exists out there.

But it is not just agricultural land and bushland that is consumed by 'sprawl', the suburbs and the fringe are also characterised as a site of over-consumption of resources as well. As the City of Darebin (submission 29) argued, 'Sustainability cannot be achieved if unfettered urban sprawl continues along with increased water consumption. Consumption levels and urban sprawl must be curbed as part of an integrated approach' (House of Representatives Standing Committee on Environment and Heritage [8]). And so sprawl is here associated with consumption and this conflation of resource consumption and sprawl suggests that the non-sprawling 'contained' city uses resources more efficiently.

But not only is sprawl inefficient and destructive there are other costs as well in terms of what 'sprawl' looks like. For instance, submission 78 argued that the word sprawl is '... aptly chosen for what, in the common perception, is an unsatisfactory and characterless mode of development of our cities, and I would extend it also to the kinds of development along the coastal fringes' (House of Representatives Standing Committee on Environment and Heritage [8]). And from a consultant (submission 79), 'Urban sprawl is the least attractive response to urban growth. It usually occupies productive land and does so in an inefficient and isolating manner often without adequate infrastructure' (House of Representatives Standing Committee on Environment and Heritage [8]). As a result, 'Australian cities need to be transformed from the sprawling, polluted and alienating cities that they are becoming' (submission 162) (House of Representatives Standing Committee on Environment and Heritage [8]).

This is, of course, despite the fact that it is in the suburbs or on the fringes of cities that the majority of Australians live. As a number of submissions noted high density urban living is reserved for a privileged minority who have the financial resources to burden the cost. Perth Area Consultative Committee (submission 62) for instance pointed out 'Perth's outer suburbs are being abandoned by young, wealthy professionals' who are choosing to live close to the central city with its 'stimulating environments, high amenity and lifestyle factors' (House of Representatives Standing Committee on Environment and Heritage [8]). During the Inquiry it was widely acknowledge that inner city areas are rich in infrastructure and the suburbs and the fringe are not but rather than framing this in terms of distributional equity the focus is instead in the majority of submissions on increasing urban densities as a way of delivering 'equitable' outcomes. 
And because the suburbs and the fringe are characterised as uniform and monotonous, inefficient and isolated, so too are the people who live there. The social costs of sprawl are often pointed out matter of factly, as though they are an inevitable result of the sprawl. Dominant amongst the social these is car dependence - as noted by one NGO (submission 194), 'Opening up more land on the fringe is not a sustainable option for affordable housing and simply locks new homeowners into car dependence' (House of Representatives Standing Committee on Environment and Heritage [8]). The private motor car is identified in a number of submissions as the main cause of unsustainability and so each proposed a simple shift from private car to cycling, walking and integrated public transport. The benefits include reduced pollution, increased space for urban green zones and community spaces. For one consultant (submission 79), "the use of the private car tends to isolate individuals and conversely that facilities within walking distance creates a casual interaction that can promote community development. To foster this sense of community replanning our cities should therefore treat the question of public transport as a priority (House of Representatives Standing Committee on Environment and Heritage [8]). Density and 'community' are here conflated demonstrating an unsubstantiated leap from 'face-to-face contact - at best acquaintanceship - to community engagement and participation' (Ziller [11]).

Low density development also has implications for health as one academic (submission 64) suggested - 'The human cost of low density lifestyles involve health and social dysfunction such and obesity and isolation' (House of Representatives Standing Committee on Environment and Heritage [8]). In a similar way submission 60 identified 'low levels of social services, reduced social support and lack of opportunities for social interaction as characteristic of low density urban developments. The submission also noted a 'Concentration of persons and households of socio economic disadvantage in fringe urban locations' along with 'Loss of identity and a sense of place' (House of Representatives Standing Committee on Environment and Heritage [8]). But added to this submission 150 from local government also noted '...social isolation often leads to boredom and anti-social behaviour - crime, domestic violence. Properties on the fringe are usually cheaper to buy, but not necessarily cheap to live in and thus encourage, and then entrench, social stratification' (House of Representatives Standing Committee on Environment and Heritage [8]). 'Sprawl' is therefore understood as a site of locational disadvantage, which is contrasted to more advantaged locations. And so the "not sprawl, or the opposite is characterised as involving '...liveable forms of residential development such as town houses, duplexes, unit blocks with communal recreational areas close to shops and public transport all with a 'village atmosphere' - instead of the " $1 / 4$ acre block of dirt" (submission 16) (House of Representatives Standing Committee on Environment and Heritage [8]). So what is required, according to Environment Business Australia is '...greater understanding of why people choose to live in featureless dormitory suburbs rather than the vibrant city centres' (submission 92) (House of Representatives Standing Committee on Environment and Heritage [8]). 
The rhetoric therefore revolves around a tale of two cities (or two storylines) - one advantaged and one disadvantaged - but where the disadvantaged simply need to become more like those who live either in 'vibrant' inner city centres, or in apartment blocks close to public transport and other services, who live in neighbourhoods that have a sense of community and of place. What community means in this context is of course rarely articulated. But what of those people who do not embrace these visions of sustainable communities? As one local government representative pointed out during public hearings:-

'...there seems to be a divide between what people want... and what governments want, in terms of pushing people into higher density living. I would say that perhaps the vocal communities are the people who have an older mind frame... Young people like me do not generally speak out about these sorts of things. However, we like mediumdensity and high density-living. I live in a unit, and I like it...Most people of my age and my friends feel the same: we do not want to have to look after a backyard, but will contribute on community days to bush care and stuff like that. It is changing' (House of Representatives Standing Committee on Environment and Heritage [9]).

And while this particular witness concedes, 'There is a certain degree to which we should listen to their concerns, but sometimes we have to look at the facts and do what is best for the whole community' (House of Representatives Standing Committee on Environment and Heritage [9]). So here we have an example of the way in which inclusive language disqualifies oppositional voices - we need to listen, but the points of view are in fact not in line with the 'facts' or what is best for the whole community. Those who resist are 'vocal' rather than cooperative.

Another example was from the Perth Area Consultative Committee (submission 62), who having developed a proposal for a sustainable community in Joondaloop in Western Australia, complained in their submission that the proposals based on 'world best practice sustainable urban principles', '... were overturned by pressure from local residents who saw the changes as threatening to their existing lifestyle (House of Representatives Standing Committee on Environment and Heritage [8]). In evidence before the Inquiry they continued 'People bought there because they liked the trees and open living. They felt that these was under threat (sic). They viewed high density as being multi rise apartments - in effect, really high density' but despite the local opposition:

The concept was very good. The material that came out with it was consistent with best practice material that we see being implemented all over the world. It was overturned by some very vocal action groups and by politics. The truth was a casualty in a lot of the information going around' (House of Representatives Standing Committee on Environment and Heritage [9]).

So the fact that there was community opposition is disqualified because it was not in line with the 'truth' or world best practice. Those who opposed the proposal were once again vocal, and in this case also political. The submission went on to argue however that, 'Sustainable development strategies that favour 
local approaches and are small scale with bottom up involvement and commitment have the most chance of success' (House of Representatives Standing Committee on Environment and Heritage [8]). And so here once again we find the familiar language of inclusion - suggesting that sustainability is consensual and therefore above politics - it's just that in this case consensus or the 'truth' could not be reached.

Community resistance to 'sustainable city' policies was understood as a behavioural problem resulting from a lack of awareness, lack of sophistication, ignorance, lack of common sense or simply poor consumer choice. Representatives from the building industry suggested that '...most home owners are not sophisticated enough to fully understand the implications of the benefit of higher initial capital costs' (House of Representatives Standing Committee on Environment and Heritage [8]). Submission 11 from a private individual argued that perhaps force was necessary because '...the public on the whole are not fully aware of the real need to change and how their own lives impact negatively on the environment (House of Representatives Standing Committee on Environment and Heritage [8]). But, as suggested by an energy provider it is also poor consumer choice - 'Traditionally, when people come into our gas shops they are much more interested in what the colour is and whether it fits' (House of Representatives Standing Committee on Environment and Heritage [9]). Or is it simply lack of common sense? As submission 85 pointed out 'With higher levels of resource consumption and lower levels of common sense, the result becomes inevitable - chronic levels of waste and a 'disposable society' (House of Representatives Standing Committee on Environment and Heritage [8]).

Two dominant cultural stereotypes (van Langenhove and Harre [12]), therefore, emerged during the Inquiry the 'suburban or fringe dweller' and the 'consumer'. The production and use of cultural stereotypes are of course not new in sustainability discourse. In his critique of Canada's Green plan Eric Darier argues that the aim of the document was to create an 'environmental citizenship', and 'environmental subjectivity' that requires the 'environmental mobilisation of the entire population' and the 'normalisation of every single individual' (Darier [13]). In the case of the Inquiry this process of normalization and control was reflected in the abundant use of pronouns in the discussion paper, and throughout the inquiry - 'we, 'our', 'us', all denote a common responsibility and a common pathway which encourages compliance. In her analysis of sustainable development policy in Norway, Straume [14] noted '...a current, general trend of authorities to appeal to the public in a way that reduces sustainable development to a private matter for individuals and households (and) ...an accompanying tendency to downplay political dialogue' (Straume [14]). Locating this tendency in the Agenda 21 process she argued that this process of individualisation centres on a common shared 'villain' that can be blamed. In the process 'democracy' or an understanding of individuals as citizens is lost.

The private, isolated individual-stripped of citizen-capacity and political community-is not only made responsible for all the wrongs of the system, but is also blamed for not changing it. For administrative 
officials, research and strategy measures focusing on people's attitudes constitute ways to distribute guilt, exercise control, avoid blame, and preserve the status quo... The result for the demos is guilt and a loss of creative power (Straume [14]).

\section{Conclusion}

The Australian Government's House of Representatives Inquiry into Sustainable Cities 2025 provides an important insight into the way in which sustainable cities are currently spoken and written about in Australia. What the case study explored in this paper demonstrates is how the focus on sprawl effectively closed down rather than opened up discussion about the future because embedded in the use of the term sprawl is a predefined conclusion. Framed as a problem of 'out of control' growth and consumption sustainable city storylines rely on a cultural stereotypes as a way of apportioning 'blame' for the unsustainability of cities and depoliticising what are in fact deeply political questions. The use of imperative and inclusive language leaves 'us' with little choice. Had the 'problem' been defined in term of distributional equity or political participation at the outset of the Inquiry then the outcome may well have been quite different.

\section{References}

[1] Becker, E, Jahn, T. and Stiess, I, Exploring uncommon ground: sustainability and the social sciences. Becker, E and Jahn, T. (eds) Sustainability and the Social Sciences: Zed Books, London and New York, pp1-22, 1999.

[2] Whitehead, M. (Re-Analysing the Sustainable City: Nature, Urbanisation and Regulation of Socio-environmental Relations in the UK Urban Studies 40 ( 7), pp. 1183-1206, 2003

[3] Harrison N.E. Constructing Sustainable Development State University of New York Press, NY, 2000

[4] Hajer, M.A. The Politics of Environmental Discourse: ecological modernisation and the policy process Claremont Press, Oxford, 1995

[5] Stone, D. Policy Paradox : The Art of Political Decision Making W.W. Norton and Company Inc, New York and London, 2002

[6] House of Representatives Standing Committee on Environment and Heritage Discussion Paper Sustainable Cities 2025 Commonwealth of Australia, Canberra, 2003

[7] Hajer, M.A. Doing Discourse Analysis: Coalitions, Practices, Meaning Chapter 4 van der Brink, M. and Metze, T. (eds) Words Matter in Policy and Planning: Discourse Theory and Method in the Social Sciences Netherlands Geographical Studies 344, Utrecht. 2006

[8] House of Representatives Standing Committee on Environment and Heritage Inquiry into Sustainable Cities; Submissions 2003-2004 http://www.aph.gov.au/house/committee/environ/cities/subs.htm 
[9] House of Representatives Standing Committee on Environment and Heritage Inquiry into Sustainable Cities: Transcripts 2004-2005 http://www.aph.gov.au/house/committee/environ/cities/hearings.htm

[10] Rein, M. and Schon Reframing Policy Discourse Fischer, F. and Forester, J. (eds) The Argumentative Turn in Policy Analysis and Planning UCL Press London 1993

[11] Ziller, A. The Community is Not a Place and Why it Matters - Case Study: Green Square Urban Policy and Research 22 (4), pp. 465-479, December 2004

[12] van Langenhove, L. and Harre, R. 'Positioning as the Production and Use of Stereotypes' Chapter 10 Harre, R. and van Langenhove, L Positioning Theory: Moral Contexts of Intentional Action pp. 127-137 Blackwell Publishers, Ltd, Oxford and Massachusetts, 1999.

[13] Darier, E Environmental Governmentality: The Case of Canada's Green Plan', Environmental Politics, 5(4), pp. 585-606, 1996

[14] Straume, I.S. Depoliticizing environmental politics: sustainable development in Norway Chapter 11 Paehlke, $\mathrm{R}$ and Torgenson, D. Managing Leviathan: Environmental Politics and the Administrative State $2^{\text {nd }}$ edition, Broadview Press, Sydney, 2005 